\title{
Tension - torsion fatigue tests on the proton exchange membrane Nafion 115 (Perfluorosulfonic acid)
}

\author{
Gonzalo Mariano Dominguez Almaraz \\ University of Michoacan (UMSNH), Santiago Tapia No. 403, Col. Centro, 58000, Morelia, México. \\ dalmaraz@umich.mx,orcid.org/0000-0002-8786-8640 \\ Luis Miguel Torres Duarte, Christian Jesús Torres Pacheco \\ University of Michoacan (UMSNH), Santiago Tapia No. 403, Col. Centro, 58000, Morelia, México. \\ Imtorres@umich.mx, cjtorres@umich.mx
}

\begin{abstract}
Biaxial tension-torsion fatigue tests are carried out on the membrane material Nafion 115 (perfluorosulfonic acid, PFSA). This polymeric material is used in fuel cells as proton exchange membrane, undergoing frequently mechanical loading of tension and torsion during its industrial life. In order to carry out the fatigue tests on this polymeric material a self-designed and self-constructed machine was used, working under the following conditions: from 0 to 50 degrees of torsion, 0 to $60 \mathrm{MPa}$ of initial tensile stresses, from room temperature $\left(22\right.$ to $\left.25^{\circ} \mathrm{C}\right)$ to $80^{\circ} \mathrm{C}$, and two values for relative humidity: environmental and saturated relative humidity. All fatigue tests were carried out at the frequency of $1.2 \mathrm{~Hz}$. This paper presents the first results, which concerns the following testing conditions: constant torsion angle of 50 degrees, 5 initial tensile stress of $60,55,50,45$ and $40 \mathrm{MPa}$, room temperature $\left(22-25^{\circ} \mathrm{C}\right)$ and environmental humidity $(50-60 \%)$. The experimental results show that fatigue endurance decreases noticeably when the tensile stress increases. In the final section are presented the fracture surfaces observed by SEM, in order to investigate the principal trends of crack initiation and propagation under this modality of biaxial fatigue loading.
\end{abstract}

KEYWORDS. Biaxial loading; Proton exchange membrane; Fatigue endurance; Nafion 115; Fracture surfaces.

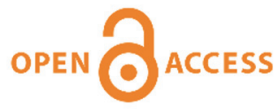

Citation: Dominguez Almaraz, G. M., Torres Duarte, L. M., Torres Pachego, C. J., Tension - torsion fatigue tests on the proton exchange membrane Nafion 115 (Perfluorosulfonic acid), Frattura ed Integrità Strutturale, 49 (2018) 360-369.

Received: 27.11 .2018

Accepted: 25.04.2019

Published: 01.07.2019

Copyright: (C) 2019 This is an open access article under the terms of the CC-BY 4.0, which permits unrestricted use, distribution, and reproduction in any medium, provided the original author and source are credited.

\section{INTRODUCTION}

$\mathrm{P}$ roton exchange membranes (PEM), used in fuel cells have been introduced during the second half of last century [1-3], as electrolytes for clean electricity production from fuel cells [4-6]. The physicochemical properties of these polymer membranes have been intensively studied in the last decades [7-10], nevertheless, the mechanical properties 
of PEM have been less studied [11-14]. In recent publications the fatigue behavior of Nafion under creep has been studied undergoing imposed humidity and temperatures [13]; and the cyclic uniaxial tension tests on Nafion under different humidities and temperatures [15]. Furthermore, tests have been carried out for ex-situ tensile fatigue and creep on catalyst coated membranes (CCMs) [16]; or a mechanical fatigue life analysis to characterize the fuel cells' PEM [14]. Other paper presents the mechanical properties of Nafion 117, measured in-plane parallel and perpendicular to the lamination direction [17]. Some principal conclusions were pointed out from that last study: water acts to improve plasticity and at high temperature an increase in stiffness is observed by stabilization of hydrophilic clusters, whereas an intermediate increase of mechanical strength is observed at low humidity content, associated with the formation of hydrogen bridge bonds and hydrates in the vicinity of sulfonic acid groups. Another paper on the Nafion and Titania/Nafion composite membranes [18], presents results on the mechanical and electrical properties of Nafion and its composite. The principal conclusions of this paper [18], were: decrease of elastic and plastic deformation on this material with temperature and water content. A swelling pressure effect is observed with water absorption, the elastic modulus of the composite membrane increases slightly whilst reducing the long-time creep effect, and the electrical resistivity increases with the mechanical applied load.

In regard the strain-stress curves and the dynamic mechanical properties on the Nafion polymer under dry and hydrated conditions, a paper [19], has enlisted the following principal conclusions: water content reduces the mechanical properties of the membrane, particularly the Young's modulus, the yield strength and the transition temperature. Another important conclusion of that paper was that the addition of contaminant ions, such as $\mathrm{Na}+, \mathrm{K}+, \mathrm{Mg} 2+, \mathrm{Cu} 2+, \mathrm{Ni} 2+$, induces a reinforcement of the stiffness and yield strength, as well as an increase in the transition temperature. Finally, in a recent paper [20], the biaxial swell and deswell process in the Nafion thin films was studied as consequence of changes in hydration; particularly, the mechanical fatigue and failure over time with the determination of swelling stress-strain in function of the humidity content. In this paper the variation of Young's modulus with the humidity content was estimated, which modifies the orientation of ionic domains inside the Nafion thin films.

The PEM used in fuel cells may undergo mechanical loading during use, which includes tension and torsion; nevertheless, no previous studies concerning the combination of tension-torsion have been conducted on this material, to the best of knowledge of the authors. The novelty of this work is oriented to analyse the combined mechanical effect of tension-torsion, which may be present in the fuel cell PEM during use. A principal challenge for polymers used as PEM is its durability, which includes thermal, physico-chemical and mechanical loading [21-23].

\section{MATERIAL AND TESTING PROCEDURE}

$\mathrm{T}$ he testing specimens were rectangular strips of Nafion 115, which were subjected to tensile and torsion loading under dry condition. Fig. 1 shows the dimensions in $\mathrm{mm}$ and general view of the Nafion 115 strip. The orientation of the strip was parallel to the drawing axis.

\section{Thickness $=0.127$}

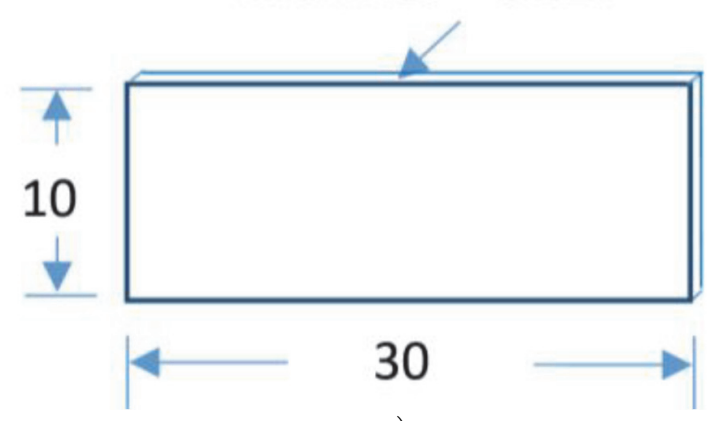

a)

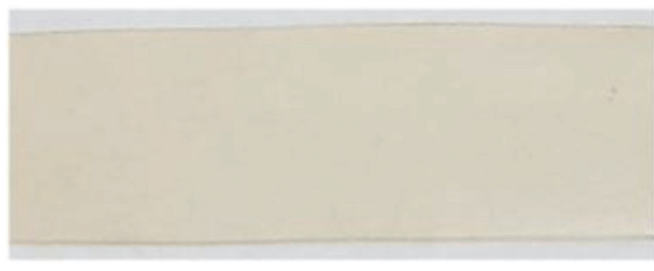

b)

Figure 1: a) Dimensions (mm), of the experimental Nafion 115 strip, and b) physical view of the experimental material.

Tests were carried out on a new self-designed and self-constructed equipment; which the principal components are the following: 
1) An acrylic frame (1) with the dimensions: $20 \times 15 \times 15 \mathrm{~cm}^{3}$ as shown in Fig. 2, contains different elements used to carry out the experiments,

2) Three step motors destined to communicate longitudinal motion (2), and torsional motion (2'), with the precision of $\pm 4 \mu \mathrm{m}$ in longitudinal motion and \pm 0.1 degrees in torsion.

3) Four thermocouple heaters (3), imposing the temperature inside the acrylic frame.

4) A testing Nafion 115 strip (4) is clamped (10 mm of each side), by the two jaws (5), of the rotation step motors.

5) A load cell (not shown), measures the applied tensile stress on the Nafion 115 strip.

6) A temperature and humidity sensor (6), is used to measure the environmental temperature and humidity.

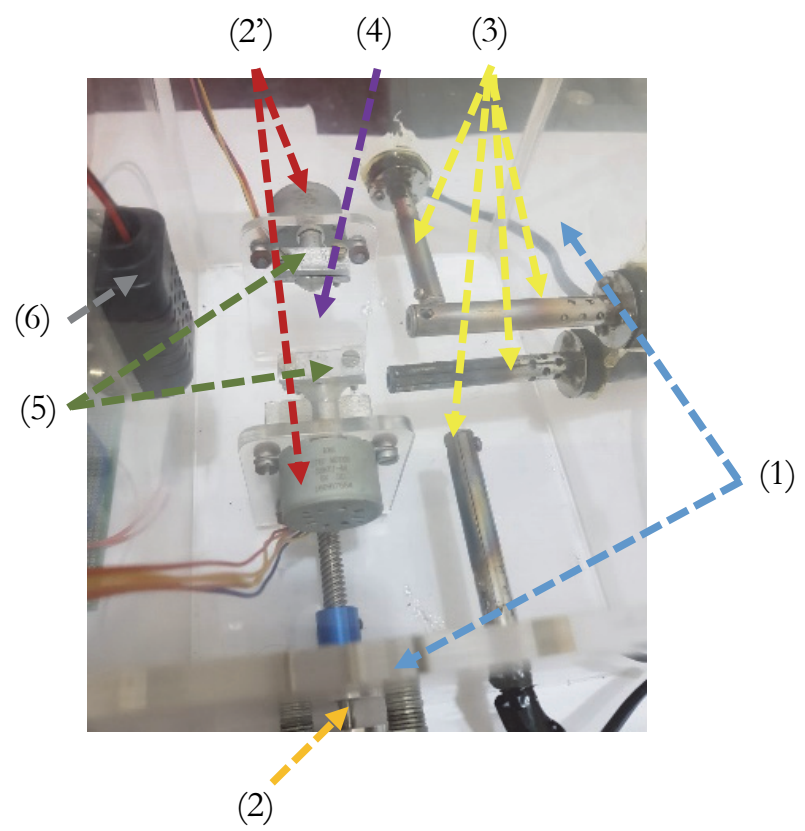

Figure 2: Experimental acrylic frame and principal components to carry out tensile and torsion tests on the Nafion 115 strip.

The tension load was imposed under the following relations: 5 steps in the tensile motor induce a longitudinal displacement of about $112 \mu \mathrm{m}$, which leads to a highest tensile stress of approximately $6.12 \mathrm{MPa}$. The Fig. 3a shows the numerical results of maximum stress $(6.16 \mathrm{MPa})$ located at the two corners of the fixed side; whereas Fig. 3b shows the displacement distribution along the Nafion strip with the highest displacement of $112 \mu \mathrm{m}$ for the free side of the Nafion strip. In Fig. 3c are illustrated the boundary conditions imposed on the Nafion 115 strip under tension loading: one side is fixed and the opposite side (free side) is stretched by uniform predetermined displacements. All numerical results in this paper were obtained using the Ansys 17.0 software.

\section{EXPERIMENTAL RESULTS.}

\section{Tensile results}

Thitial tests were carried out to evaluate the stress-strain curve of this polymeric material at environmental temperature $\left(22-25^{\circ} \mathrm{C}\right)$ and $50-60 \%$ of relative humidity. Under this condition, only the step motor for tensile displacement was used for this purpose with the following working relationship: 10 steps in the motor induces $224 \mu \mathrm{m}$ of longitudinal displacement in the Nafion 115 strip, implying approximately 12.24 MPa of maximum tensile stress. In Fig. 4 is plotted the stress-strain curve obtained by logarithmic interpolation of experimental points; these points are the average of 5 experimental tests, each.

\section{Fatigue endurance results}

Fatigue endurance tests on the Nafion 115 strip undergoing constant torsion stress and variable tension stress were obtained at environmental temperature $\left(22-25^{\circ} \mathrm{C}\right)$ and relative humidity $\mathrm{RH}=50-60 \%$. Specimens were attached to the device at 
the two ends with $1 \mathrm{~cm}$ of the Nafion 115 strip between jaws, and tensile stress was applied progressively to attain the nominal value of: 40, 45, 50, 55 and $60 \mathrm{MPa}$. All results reported in this paper were obtained at the torsion frequency of 1.2 $\mathrm{Hz}$, constant torsion angle of 50 degrees, and with the loading rate $\mathrm{R}=-1$. The failure criterion applied in this study was defined as the perceptible crack initiation in the polymeric strip, according to previous works [13, 24].
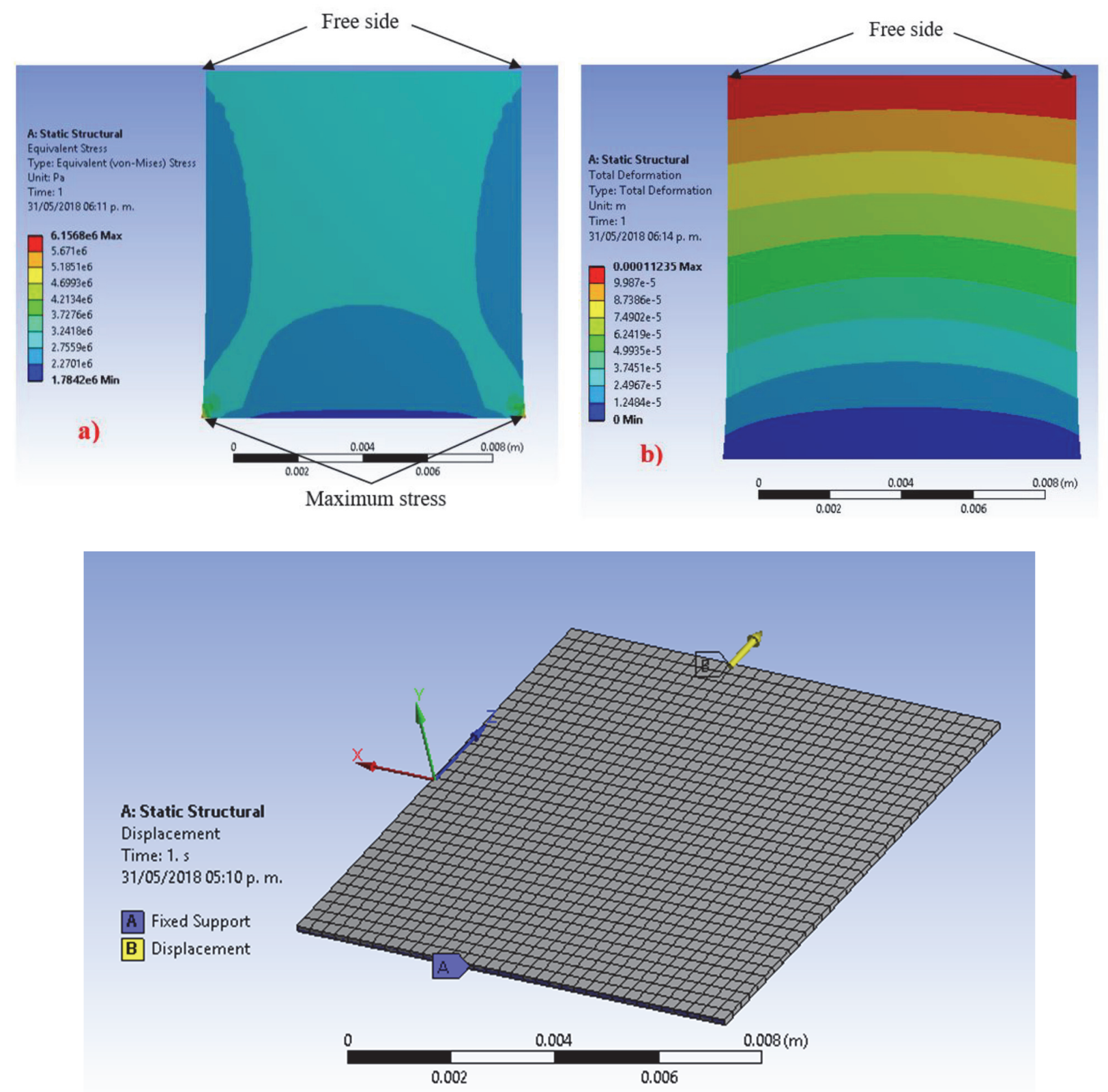

Figure 3: a) Stress distribution along the Nafion 115 strip, with $112 \mu \mathrm{m}$ of displacement at the free side, b) Corresponding displacement on the Nafion 115 strip, c) Boundary conditions imposed on the Nafion 115 strip for numerical simulation

The fatigue endurance results are plotted in Fig. 5. Fatigue life is revealed close to 200000 cycles when the tensile applied load is close to $60 \mathrm{MPa}$; whereas this property increases close to 900000 cycles when decreasing the tensile stress to $40 \mathrm{MPa}$. A tendency line is obtained by logarithmic interpolation of experimental points. In addition, it is observed that dispersion of experimental points is higher for the high tensile applied load; the fatigue endurance is less scattered for relative low applied load. 


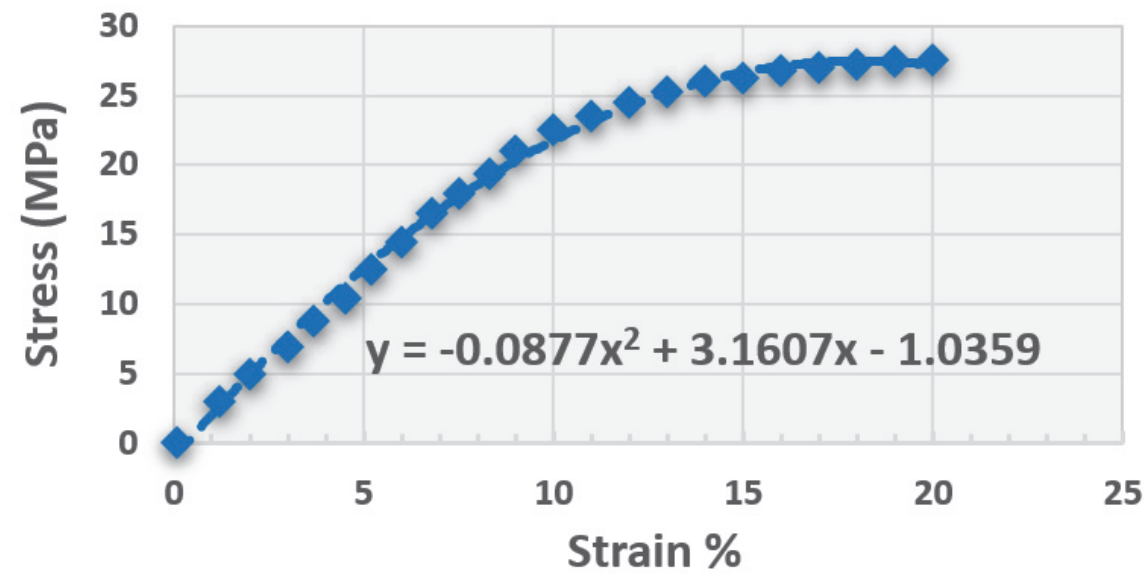

Figure 4: Experimental results of stress-strain curve, and polynomial interpolated equation (dashed line), for Nafion 115.

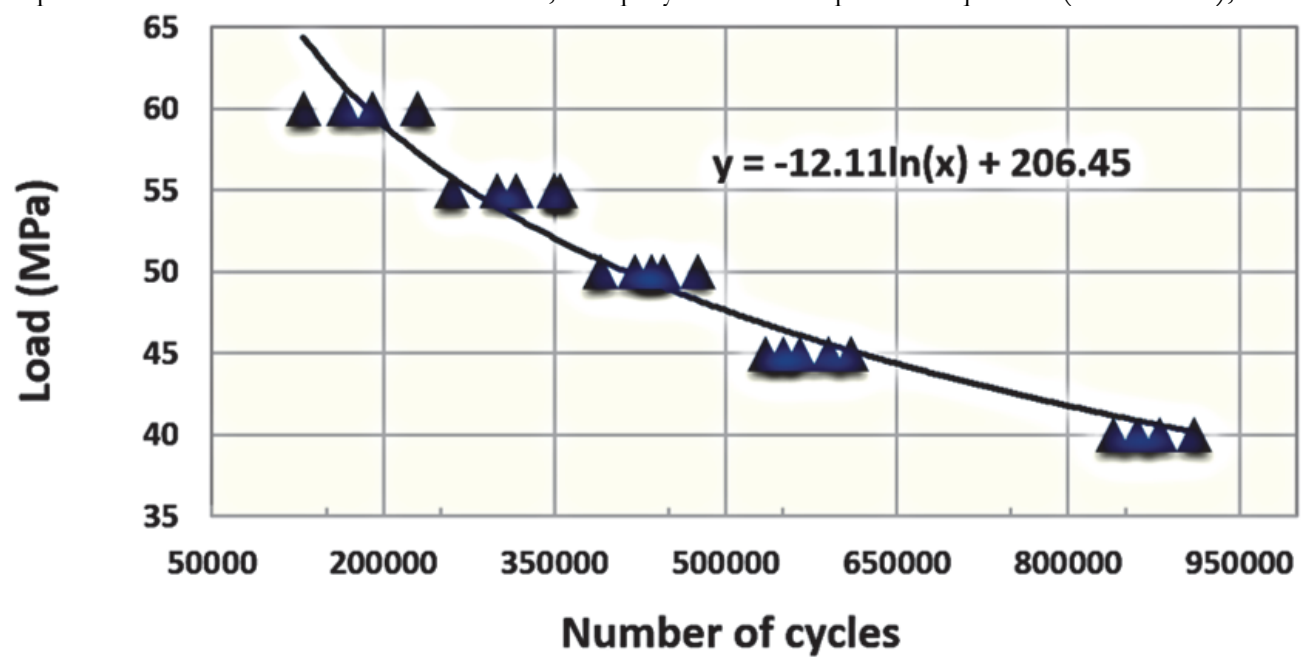

Figure 5: Fatigue endurance S-N curve for the Nafion 115 strip under tension and torsion, and environmental conditions $\left(22-25^{\circ} \mathrm{C}\right.$, $\mathrm{RH}=50 \%, \mathrm{R}=-1$ and $\mathrm{f}=1.2 \mathrm{~Hz})$.

Fracture analysis of Nafion 115 under biaxial loading: tension and torsion.

Two sites of crack initiation were observed under biaxial loading on this polymeric material: at one corner of the Nafion115 strip, where the metallic jaws attach the testing specimen; at this zone is observed the highest stress from the numerical simulation. The other site of crack initiation is located close to the center of the polymeric strip, where the combine effect of tension and torsion induces stress concentration.

Crack initiates perpendicularly to applied tensile stress, as shown in Fig. 6a; then, it bifurcates with an angle close to 20 degrees when the crack size is close to $5.5 \mathrm{~mm}$, Figs. $6 \mathrm{a}$ and $6 \mathrm{~b}$. The last behavior is attributed to the torsion loading, when the mode II of crack propagation is higher than the initial mode I.

\section{DISCUSSION}

he values plotted in Fig. 4 are revealed higher compared to previous tensile results [15]. Two principal factors are at the origin of this difference: a) $127 \mu \mathrm{m}$ of thickness in the present work and $25 \mu \mathrm{m}$ for the referred work; b) a higher thickness is related to a high rigidity of cross-linked polymeric chains [25].

Mode I of crack propagation is predominant at crack initiation; nevertheless, the mixed mode I and II involves a transition when the rate: tensile fracturing stress/shear fracturing stress, decreases to a determined value. The bifurcation observed in the crack path of the fracture surface in this polymer, shown in Fig. 6b, reveals such transition. 

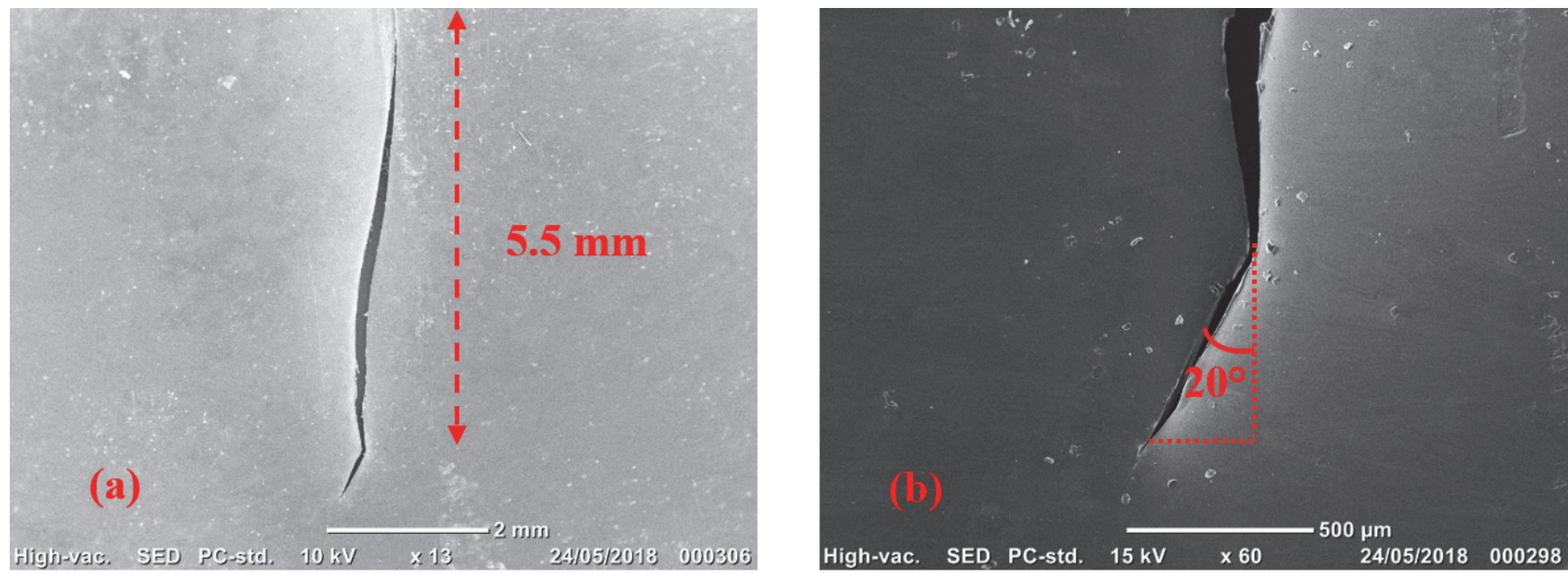

Figure 6: Fracture of the Nafion 115 strip under biaxial loading: tension and torsion.

Considering a predominant elastic crack propagation behavior on this polymer under the mentioned loading condition, and using the bi-dimensional stress in the polar coordinate system $(r, \theta)$, the corresponding equations are:

$$
\begin{aligned}
& \sigma_{r r=} \cos \left(\frac{\theta}{2}\right)\left[K_{I}\left(1+\sin ^{2} \frac{\theta}{2}\right)+K_{I I}\left(\frac{3}{2} \sin \theta-2 \tan \frac{\theta}{2}\right)\right] \\
& \sigma_{\theta \theta}=\cos \left(\frac{\theta}{2}\right)\left[K_{I} \cos ^{2} \frac{\theta}{2}-\frac{3}{2} K_{I I} \sin \theta\right] \\
& \tau_{r \theta}=\frac{1}{2 \sqrt{2 \pi r}} \cos \frac{\theta}{2}\left[K_{I}(\sin \theta)+K_{I I}(3 \cos \theta-1)\right] \\
& \sigma_{\text {茫 }}=\left\{\begin{array}{ll}
0 & (\text { plane stress }) \\
v\left(\sigma_{r r}+\sigma_{\theta \theta}\right) & \text { (plane strain })
\end{array}\right\}
\end{aligned}
$$

where $K_{I}$ and $K_{I I}$ are the stress intensity factor in mode $I$ and II, respectively. The thickness of the Nafion 115 strip is very thin $(127 \mu \mathrm{m})$; then, the plane stress is assumed $\left(\sigma_{z z}=0\right)$. The ductility of materials is defined as $\sigma_{\mathrm{c}} / \tau_{\mathrm{c}}$, where $\sigma_{\mathrm{c}}$ is the fracture strength of material in pure tension and $\tau_{\mathrm{c}}$ is the fracture strength of material in pure shear. The rate $\mathrm{K}_{\mathrm{I}} / \mathrm{K}_{\mathrm{II}}$ and the ductility of material allow determining the transition from the tensile failure to shear failure, as shown in Fig. 7.

The ductility of Nafion 115 is determined with the values: $\sigma_{\mathrm{c}}=43 \mathrm{MPa}$ [26], and $\tau_{\mathrm{c}}=26.5 \mathrm{MPa}$ [27]; which yields for this material: $\sigma_{c} / \tau_{c}=26.5 / 43=0.61627$. The last value is represented with the dashed line in Fig. 7 .

On the other hand, the stress intensity factors KI and KII for an edge-cracked strip in mode I and II, are calculated by the following equations $[28,29]$ :

$$
\begin{aligned}
& \boldsymbol{K}_{\boldsymbol{I}}=\frac{P \sqrt{a}}{B W}\left[0.955+0.618\left(\frac{a}{W}\right)-7.43\left(\frac{a}{W}\right)^{2}+23.83\left(\frac{a}{W}\right)^{3}-30.52\left(\frac{a}{W}\right)^{4}+15.96\left(\frac{a}{W}\right)^{5}\right] \\
& \boldsymbol{K}_{\boldsymbol{I I}}=\frac{2 Q}{\sqrt{\pi a}}\left[1.3-\frac{0.65 a}{W}+0.37\left(\frac{a}{W}\right)^{2}+0.28\left(\frac{a}{W}\right)^{3}\right] /(1-a / W)^{0.5}
\end{aligned}
$$




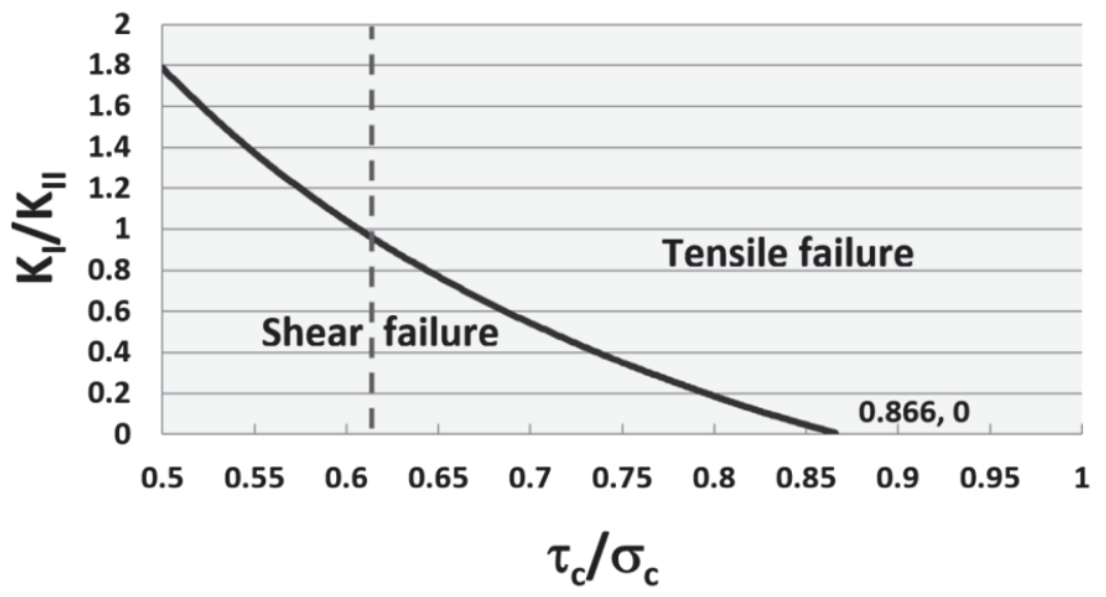

Figure 7: Transition from tensile to shear failure in function of the rate $K_{I} / K_{I I}$ and the ductility $\sigma_{c} / \tau_{c}$.

In the last two equations, $a$ represents the crack length, W the width of the strip, $\mathrm{B}$ the thickness of the strip, $\mathrm{P}$ the tensile applied load on mode I, and Q the shear stress per unit of length at the fracture surface.

The load P along the crack propagation is measured physically using a load cell and is obtained numerically by the finite element method. Concerning the shear stress per unit length Q, it is obtained by numerical simulation as follows: the shear stress along the crack was computed to obtain an average value, Fig. 8; then, multiplied by the crack size to obtain the corresponding Q.

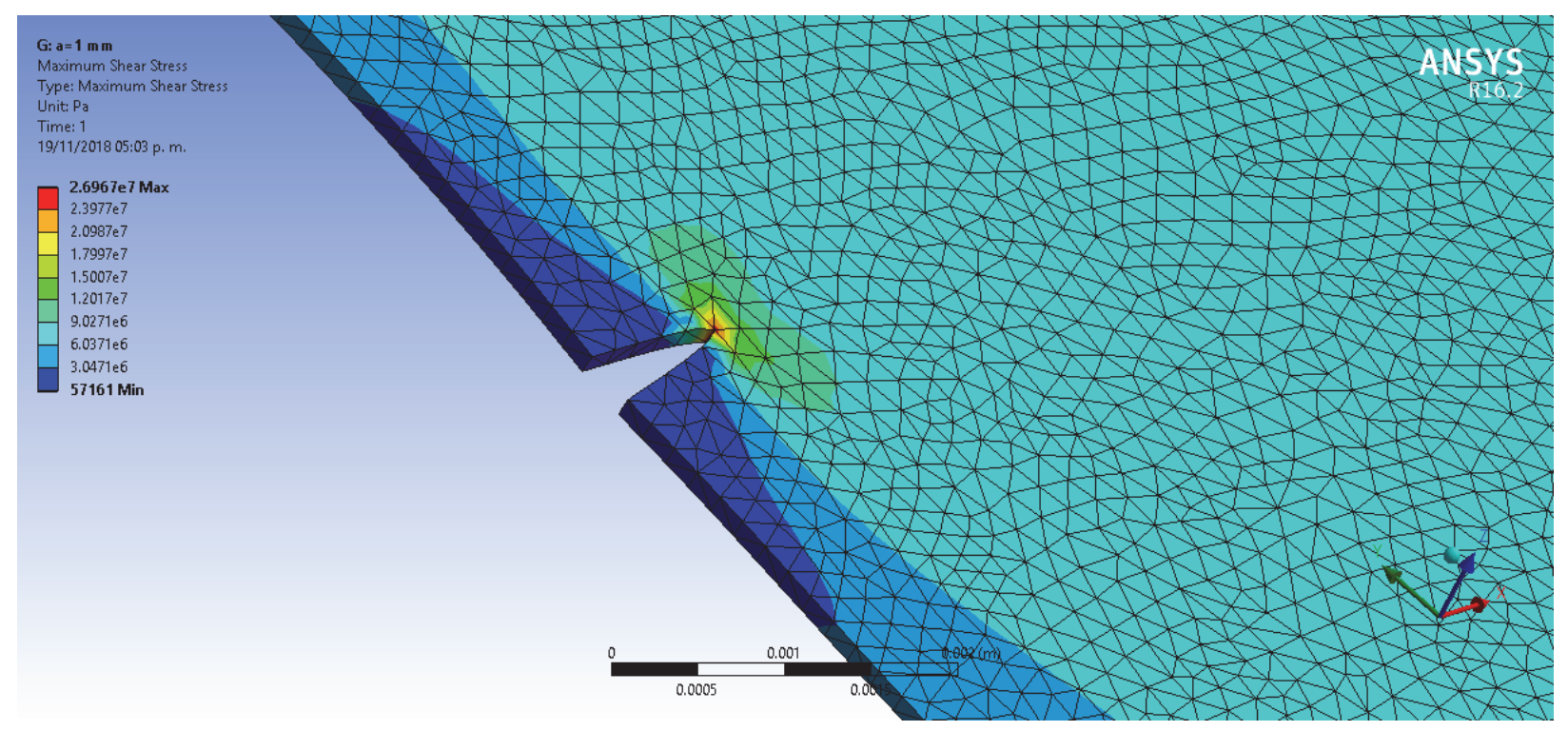

Figure 8: Shear stress along the crack, for the crack size of $1.0 \mathrm{~mm}$.

In Fig. 9 are represented the evolutions of $K_{I}$ and $K_{I I}$ with the crack propagation, calculated with the Eqns. 5 and 6 , respectively. These values are obtained using the experimental and numerical values, as described previously.

The results plotted in Fig. 9 shows that $\mathrm{K}_{\mathrm{II}}$ becomes higher compared to $\mathrm{K}_{\mathrm{I}}$, when the crack size is close to $5.5 \mathrm{~mm}$, Fig. 6 . At this point, the mode II of crack propagation becomes predominant: crack propagation presents a bifurcation close to 20 degrees, as depicted in Fig. 6b. The combined effect of tension and torsion changes the crack propagation modality for this material with the ductility $\sigma_{\mathrm{c}} / \tau_{\mathrm{c}}=0.61627$, when $\mathrm{KII} \approx \mathrm{KI}$, as shown in Fig. 7 . 


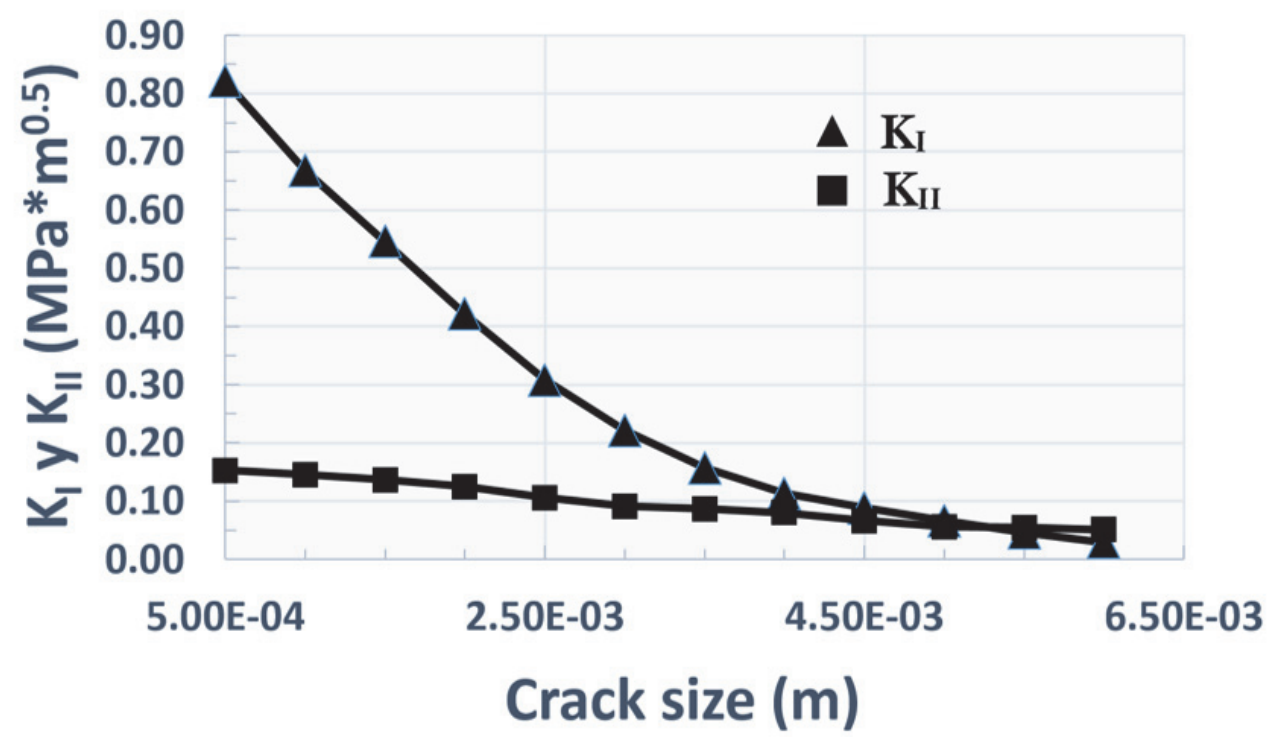

Figure 9: Evolution of $\mathrm{K}_{\mathrm{I}}$ and $\mathrm{K}_{\mathrm{II}}$ along the crack propagation.

\section{CONCLUSIONS}

$\mathrm{T}$

he following conclusions may be extracted from the present work:

- The fatigue endurance of the proton exchange membrane Nafion 115 has been determined under tension and torsion.

- The experimental machine to carry out biaxial loading: tension and torsion tests on this polymeric material, has been selfdesigned and self-constructed.

- The results shown in this paper are obtained under a constant torsion angle of 50 degrees, at room temperature and with relative humidity comprised between 50 and $60 \%$.

- A logarithmic regression curve is obtained from the experimental points, showing the tendency of fatigue endurance of this material, under the described loading conditions.

- Stress intensity factors $K_{I}$ and $K_{I I}$ are evaluated along the crack propagation in the Nafion 115 strip.

- Tensile crack propagation changes to shear crack propagation, when the crack size attains $5.5 \mathrm{~mm}$ approximately, for this material with ductility $=\sigma_{\mathrm{c}} / \tau_{\mathrm{c}}=0.61627$.

\section{ACKNOWLEDGEMENTS}

7 he authors express their gratitude to the University of Michoacán in Mexico for the received support in the development of this work. A special mention of gratitude CONACYT (The National Council for Science and Technology, Mexico), for the financial support destined to this study by the program grant: CB- 241117- 2014.

\section{REFERENCES}

[1] Peighambardoust, S.J., Rowshanzamir, S., Amjadi, M. (2017). Review of the proton exchange membranes for fuel cell applications, Int. J. of Hydro. Energy, 35(17), pp. 9349-9384. DOI: 10.1016/j.ijhydene.2010.05.017.

[2] Millington, B., Du S., Pollet, B.G. (2011). The effect of materials on proton exchange membrane fuel cell electrode performance, J. of Pow. Sources, 196(21), pp. 9013-9017. DOI: 10.1016/j.jpowsour.2010.12.043.

[3] EG\&G Technical Services, Inc. (2004). Fuel Cell Handbook (Seventh Edition), Morgantown, West Virginia 265070880. ISBN-10: 1365101134. 
[4] Carrette, L., Friedrich, K.A., Stimming, U. (2001). Fuel Cells - Fundamentals and Applications, Fuel Cells, 1(1), pp. 539. DOI: $10.1002 / 1615-6854(200105)$.

[5] Sharaf, O.Z., Orhan M.F. (2014). An overview of fuel cell technology: Fundamentals and applications, Renew. and Sust. Energy Reviews, 32, pp. 810-853. DOI: 10.1016/j.rser.2014.01.012.

[6] Mekhilef, S., Saidur, R., Safari A. (2012). Comparative study of different fuel cell technologies, Renew. and Sust. Energy Reviews, 16(1), pp. 981-989. DOI: 10.1016/j.rser.2011.09.020.

[7] Hickner, M.A., Pivovar, B.S. (2005). The Chemical and Structural Nature of Proton Exchange Membrane Fuel Cell Properties, Fuel Cells, 5(2), pp. 213-229. DOI: 10.1002/fuce.200400064.

[8] Gashoul, F., Parnian, M.J., Rowshanzamir, S. (2017). A new study on improving the physicochemical and electrochemical properties of SPEEK nanocomposite membranes for medium temperature proton exchange membrane fuel cells using different loading of zirconium oxide nanoparticles, Int. J. of Hydro. Energy, 42(1), pp. $590-602$. DOI: $10.1016 /$ j.ijhydene.2016.11.132.

[9] El-kharouf, A., Chandan, A., Hattenberger, M., Pollet, P.G. (2012). Proton exchange membrane fuel cell degradation and testing: Review, J. of the Ener. Institute, 85(4), pp. 188-200. DOI: 10.1179/1743967112Z.00000000036.

[10] Yang, Ch., Srinivasan, S., Bocarsly, A.B., Tulyani, S., Benziger, J.B. (2004). A comparison of physical properties and fuel cell performance of Nafion and zirconium phosphate/Nafion composite membranes, J. of Memb. Science, 237, pp. 145-161. DOI: 10.1016/j.memsci.2004.03.009.

[11] Huang, X., Solasi, R., Zou, Y., Feshler, M., Reifsnider, K., Condit. D., Burlatsky, S., Madden, T. (2006). Mechanical endurance of polymer electrolyte membrane and PEM fuel cell durability, J. of Poly.Scie., Part B: Poly. Phys., 44(16), pp. 2346 - 2357. DOI: 10.1002/polb.20863.

[12] Tan, J., Chao, Y.J., Van Zee, J.W., Li, X., Wang, X., Yang, M. (2008). Assessment of mechanical properties of fluoroelastomer and EPDM in a simulated PEM fuel cell environment by microindentation test, Mat. Sci. and Eng. A, 496(1-2), pp. 464-470. DOI: 10.1016/j.msea.2008.05.052.

[13] Solasi, R., Huang, X., Reifsnider, K. (2010). Creep and stress-rupture of Nafion ${ }^{\circledR}$ membranes under controlled environment, Mech. of Mat., 42(7), pp. 678-685. DOI: 10.1016/j.mechmat.2010.04.005.

[14] Aindow, T.T., O’Neil, J. (2011). Use of mechanical tests to predict durability of polymer fuel cell membranes under humidity cycling, J. of Power Sour., 196(8), pp. 3851-3854. DOI: 10.1016/j.jpowsour.2010.12.031.

[15] Khorasany, R.M.H., Alavijeh, A.S., Kjeang, E., Wang, G.G., Rajapakse, R.K.N.D. (2015). Mechanical degradation of fuel cell membranes under fatigue fracture tests, J. of Power Sour., 274, pp. 1208-1216.

DOI: $10.1016 /$ j.jpowsour.2014.10.135

[16] Alavijeh, A.S., Venkatesan, S.V., Khorasany, R.M.H., Kim, W.H.J., Kjeang, E. (2016). Ex-situ tensile fatigue-creep testing: A powerful tool to simulate in-situ mechanical degradation in fuel cells, J. of Power Sour., 312, pp. $123-127$. DOI: $10.1016 / j . j p o w s o u r .2016 .02 .053$.

[17] Bauer F., Denneler, S., Willert- Porada, M. (2005). Influence of temperature and humidity on the mechanical properties of Nafion ${ }^{\circledR} 117$ polymer electrolyte membrane, , J. of Poly. Scie., Part B: Poly. Phys., 43(7), pp. 786 - 795.

DOI: $10.1002 /$ polb.20367

[18] Satterfield, M.B., Majsztrik, P.W., Ota, H., Benzinger, J.B., Bocarsly, A.B. (2006). Mechanical properties of Nafion and titania/Nafion composite membranes for polymer electrolyte membrane fuel cells, J. of Poly. Scie., Part B: Poly. Phys., 44(16), pp. 2327-2345. DOI: 10.1002/polb.20857.

[19] Kundu, S., Simon, L.C, Fowler, M., Grot, S. (2005). Mechanical properties of Nafion ${ }^{\text {TM }}$ electrolyte membranes under hydrated conditions, Polymer, 46(25), pp. 11707-11715. DOI: 10.1016/j.polymer.2005.09.059.

[20] Page, K.A., Shin, J.W., Eastman, S.A., Rowe, B.W., Kim, S., Kusoglu, A., Yager, K.G., Stafford, G.R. (2015). In Situ Method for Measuring the Mechanical Properties of Nafion Thin Films during Hydration Cycles, Appl. Mat. and Interfaces, 7(32), pp. 17874-17883. DOI: 10.1021/acsami.5b04080.

[21] El-kharouf, A., Chandan, A., Hattenberger, M., Pollet, B. G. (2012). Proton exchange membrane fuel cell degradation and testing: review, J. of the Ener. Inst., 85(4), pp. 188-200. DOI: 10.1179/1743967112Z.00000000036.

[22] Chen, B., Cai, Y., Shen, J., Tu, Z., Chan, S.H. (2018). Performance degradation of a proton exchange membrane fuel cell with dead-ended cathode and anode, Appl. Thermal Eng., 132, pp. 80-86.

DOI: 10.1016/j.applthermaleng.2017.12.078.

[23] Gittleman, C.S., Coms, F.D., Lai, Y.-H. (2012). Chapter 2 - Membrane Durability: Physical and Chemical Degradation, Polymer Electrolyte Fuel Cell Degradation, pp. 15-88. DOI: 10.1016/B978-0-12-386936-4.10002-8.

[24] Kai, Y., Kitayama, Y., Omiya, M., Uchiyama, T., Kumei, H. (2014). In situ observation of deformation behavior of membrane electrode assembly under humidity cycles, J. of Fuel Cell Sci. and Tech., 11(5), pp. 051006-051013. DOI: $10.1115 / 1.4028155$ 
[25] Kumari, M., Sodaye, H.S., Sen, D., Bindal, R.C. (2018). Properties and morphology studies of proton exchange membranes based on cross-linked sulfonated poly (ether ether ketone) for electrochemical application: Effect of crosslinker chain length, Sol. Est. Ionics, 316, pp. 75-84. DOI: 10.1016/j.ssi.2017.12.027.

[26] https://www.chemours.com/Nafion/en_US/assets/downloads/nafion-extrusion-cast-membranesproductinformation.pdf.

[27] Silberstein, M.N., Pillai, P.V., Boyce, M.C. (2011). Biaxial elastic-viscoplastic behavior of Nafion membranes, Polymers, 52(2), pp. 529-539. DOI: 10.1016/j.polymer.2010.11.032.

[28] Saxena, A., Bassi, F., Nibur, K., Newman Jr, J.C. (2017). On single-edge-crack tension specimens for tensioncompression fatigue crack growth testing, Eng. Fract. Mech., 176, pp. 343-350.

DOI: $10.1016 /$ j.engfracmech.2017.03.030.

[29] Tada, H., Paris, P.C., Irwin, G.R. (1973). The Stress Analysis of Cracks Handbook, Third Edition, New York - London, Wiley \& Sons, 696. 